\title{
Karnofsky Performance Status 40
}

National Cancer Institute

\section{Source}

National Cancer Institute. Karnofsky Performance Status 40. NCI Thesaurus. Code C105714.

Disabled; requires special care and assistance. 